UDC 821.161.1.-3.09

DOI https://doi.org/10.32841/2409-1154.2021.48-4.24

\author{
Pavelieva A. K., \\ Candidate of Philological Sciences, \\ Associate Professor at the Germanic Philology and Translation Department \\ National University "Yuri Kondratyuk Poltava Polytechnic"
}

\author{
Radchenko Yu. S., \\ fourth-year Student at the Faculty of Humanities \\ National University "Yuri Kondratyuk Poltava Polytechnic"
}

\title{
ARTISTIC TIME AND SPACE CONTINUUMS IN NIKOLAI GOGOL'S PROSE: THEORETICAL ASPECT
}

Summary. The article is devoted to the concepts of literary time or "artistic time continuum", literary space or "artistic space continuum" and "chronotope" (according to M.M. Bakhtin) as significant categories of poetics and forms of existence of the world depicted by the writer and their definition in modern literary criticism. Since the $60 \mathrm{~s}-70 \mathrm{~s}$ of the XX century, the interest to the categories of literary time and literary space has been growing in literary criticism. These literary categories are considered as plot-creating and genrecreating characteristics of the author's worldbuilding, which serve as the mirror of psychologism and reflect the author's philosophy, worldview and world perception, the author's intention and the tasks that he set himself, allow us to reveal certain patterns of functioning of his literary world. There have been investigated various types of literary time and space and their peculiar features (saturation of time with events and of space with things, slow or fast pace of time, nearness or farness of space and etc.), such traditional spatial landmarks as "house" (the image of closed space), "threshold", "window", "door" (borders between two types of space), the important role of artistic chronology. The author underlines the fact that literary space, literary time and chronotope (as well as microchronotopes, toposi, loci and chronotopic motives) are of topmost importance as they are not only interwoven with unravelling of the plot, but also characterize the narrator or the storyteller and the characters of the literary writing. In the late 70 s of the XX century, this scientific topic began to be partially developed in Gogol studies, therefore the author of the article has given an overview of the most prominent studies, dealing with the categories of time and space in literature, as well as the most prominent scientific treatise, dedicated to the problem of spatiotemporal organization of Gogol's prose. In particular, the paper considers "pointlike" space-time, devilish play with space, blurring the lines between the real and the fantastic worlds, cultural-historical and natural-landscape spatial modes of Gogol's short-stories.

Key words: literary time, literary space, chronotope, artistic time continuum, artistic space continuum.

Articulation of issue and its connection with important scientific and practical tasks. Literary time and literary space are the most important components of the structure of any writer's artistic world. These are significant categories of poetics and forms of existence of the world depicted by the writer. They have been considered for about half a century, but they have not yet been sufficiently studied in all their diversity.
In modern literary criticism, time and space, the ways of their implementation are considered as the mirror of psychologism, as the categories reflecting the author's philosophy, worldview and world perception. The analysis of the categories of literary time and space allows us to understand the peculiarities of the poetics of the writer, the author's intention and the tasks that he set himself, to reveal certain patterns of functioning of his literary world.

Despite the increasing interest of researchers to the categories of literary time and space or "artistic time continuum", "artistic space continuum" and "chronotope" (according to M.M. Bakhtin) in a literary work, the problem of defining these concepts and studying them in the context of literary works of various writers continues to be a challenging theoretical problem. Many of the well-known literary critics addressed this problem. For example, P.A. Florensky in the book "Analysis of spatiality and time in artistic works" [1], M.M. Bakhtin in his works "The author and the hero in aesthetic activity" [2] and "The forms of time and chronotope in the novel" [3]. D.S. Likhachev [4], Yu.M. Lotman [5], V.N. Toporov [6], A.M. Pyatigorsky [7], A.K. Pavelieva [8; 9] have also conducted research on literary time and space.

Actual scientific researches and issues analysis. Since the 60-s - 70-s of the XX century, the interest to the categories of literary time and literary space has been growing in literary criticism. This is evidenced by the works of S.A. Babushkin, M.M. Bakhtin, A.B. Botnikova, N.K. Gey, D.S. Likhachev, Yu.M. Lotman, N.A. Poznyakova, N.F. Rzhevskaya, N.G. Sivokhina, Z.Ya. Turaeva and others. Since the beginning of the 1980-s, the term "chronotope" has been actively used in everyday scientific language.

The researchers set themselves the task of characterizing this literary phenomenon, its features and forms of expression to the fullest extent possible, and determining its place in the composition of a literary writing. In the late 70 -s of the XX century, this scientific topic began to be partially developed in Gogol studies (A.G. Kovalchuk, Yu.M. Lotman, Yu.V. Mann). Since the beginning of the XXI century only, N.S. Bolkunova, I.F. Zamanova, V.O. Korkishko, A.K. Pavelieva defended dissertations, dedicated to the study and comprehension of literary time and space in the works of N.V. Gogol. However, the problem of literary time and space in Gogol's works was most actively developed at the turn of the millennium. The beginning of the new millennium was marked by the emergence of comparative studies of the spatiotemporal worldbuilding in the works of Gogol 
and other writers (V.S. Voronin, S.G. Grigorenko, M.A. Trenogina, S.V. Ushakova, etc.), which indicates the relevance of this problem in literary studies.

Therefore, the goal of research is to analyze different forms of realization of literary time, literary space and chronotope in literary studies in general and in the early prose of N.V. Gogol in particular. This goal may be achieved by solving the following problems:

- to define "literary time", "literary space" and "chronotope";

- to identify various forms of concretization of literary time and space;

- to indicate specific features of literary time and space;

- to determine the role of time and space in unravelling of the plot and the fates of the heroes, as well as their importance in the structure of the stories;

- to give an overview of forms of embodiment of literary time, literary space and chronotopes in Gogol's prose.

Exposition. The analysis of different forms of realization of literary time and space in poetry and prose (both separately and in close relationship) attracts the attention of literary scholars. Researchers have made attempts to identify the forms of concretization of literary time and space and to investigate the problems of the relationship between time and space; to determine the role of these categories in unravelling of the plot and the fates of the heroes, as well as their importance in the structure of literary writings; to reveal the satiation of literary space and intensity of literary time; to indicate the role and effect of organizing literary time and space. Undoubtedly, the chronotopic analysis of the text today is an important aspect of understanding both the worldbuilding of a separate literary work, and the philosophical perception of the writer's works as a whole.

So, in the "Literary encyclopaedical dictionary" literary time and space are characterized as the most important characteristics of the literary image, which "provide perceptual unity of literary reality and organize contexture of the work", since the literarypoetic image, "formally unfolding in time (as self-consistency of the text), by its content reproduces the spatio-temporal worldbuilding, moreover, in its symbolic, ideological, axiological aspect" [10, p. 487].

There are many different classifications of literary time and space in a literary work. In general, literary time in a work of fiction can be biographical, cosmic, sacred, calendar, daily, mythological, social, historical, socio-historical, political, irreal, infernal, fantastic, demonic, diabolical, divine; objectively or subjectively experienced. Time flies in different ways in the city and in the countryside, in every single country and in various places of the earth, in different eras and according to different beliefs. Time in a literary work flies slowly or quickly, gradually and chronologically or fragmentarily, and in the perception of each hero - in different ways. Noteworthy is that literary time has its own specifics in each separate literary space.

Literary space can be open and closed, close and distant, limited, separated and delimited, objectively visible and imaginary, earthly, heavenly, underwater, underground, urban and rural, forest, field, nundinal, wedding, home, family, etc.

In theoretical works, such traditional spatial landmarks as "house" (the image of closed space), "threshold", "window", "door" (borders between two types of space) are most often distinguished. The important role of artistic chronology is often noted. The characteristics of the chronotopes, defined by M.M. Bakhtin, are of great importance. It is widely thought, that they have been preserved by modern letters in customized forms. For example, such contemporary chronotopes as "bus-station" or "airport" correspond to the old "crossroads" or "roadside tavern". Note should be made of the "evolution" of the depiction of time and space in imaginative writing - from archaic forms (coinciding with time, orientation in collective or historical track of time) to naive realism (observation of the unity of time and place) and modern European novel (the author gained the right to manage novelistic time as his initiator and creator). "From now on, timeliness can be broad as much as desired, the pace of the narration can be arbitrarily uneven, parallel "theaters of action", reversal of time and entrance into the future known to the narrator only have become permissible and functionally important" [10, p. 487]. In literary works of the XIX century, chronicle-everyday time, in contrast to eventrelated time, no longer has absolute beginning and absolute end. The writers challenge stereotypes and create new spatiotemporal planes. Thus, Chekhov merged event-related time with everyday life to indistinguishable unity. Dostoevsky, on the contrary, focused the plot within the boundaries of watershed, turning, crisis time of critical tests, which corresponds to the space of "threshold", "random shelter", "meeting room" measured by the heroes' steps, corresponding to the situations of crime (overstepping).

The "Literary encyclopaedical dictionary" examines such tendencies of the spatio-temporal organization of literary works of the XX century, as signposting of the symbolic plan by the realism of the spatio-temporal panorama; the use of closed literary time of a fairy tale or paroemia, excluded from historical track of time; referring to the character's memory as to internal space for unfolding events, etc.

Researchers are increasingly turning to the study of the chronotope as the fusion of the space-time "layers" of a literary work. "Literary dictionary guide" gives the following definition of the chronotope: "Chronotope (from the Greek "chronos" - time and "topos" - place) - is interrelation of temporal and spatial characteristics of the events, depicted in a piece of fiction". Time in the literary world (work) is considered as a multidimensional category, which is divided into plot-narrative and depictivenarrational time. In such a way, it becomes possible to discriminate when the depicted events took place and when they were retold by the storyteller or the narrator as a witness and participant of these events or only as a communicant who somehow got to know about them. Literary time is closely related to its saturation with important events and their spatial scope. Literary time in a work of fiction also runs counter to the place of unfolding developments or the place of stay of the characters, for example, local interior and scenery may broaden into the big wide world by means of retrospection (recollections, flashbacks, allusions, mentions, dreams, delirious talks and etc.). The character and peculiarities of the chronotope depend on the genre of the literary work, are inseparable from its subjective system and are important constituent of stylistic determinancy of every literary creation" [11, p. 714].

It should be noted that in modern literary criticism the category of chronotope does not have a clear, unified definition. There are many works, the main purpose of which is to highlight new forms of embodiment of time and space in a piece of writing.

Despite the fact that, starting from the 1960-1970-s, the interest to the problem of literary time and space in a work of fiction did not 
disappear or decline, the chronotope of Gogol's early prose has not been sufficiently studied. Most authors focus on the peculiarities of literary time and space in the novel "Dead Souls" and in a satirical play "The Government General". When analyzing "the Ukrainian" stories by Gogol, the researchers, as a rule, give prominence to such features of Gogol's "demonic" world as irreality and fantastic nature of the space depicted by the writer. According to T.V. Bovsunovskaya, in the works by Gogol, the circle and cyclicism are often considered as a certain regularity of public thinking and development. For instance, Khoma Brut, grandfather form the short-story "The Lost Letter", Chichikov, Foma's grandfather form the short-story "A Bewitched Place" and others all of them come back to the certain space, being led by mystical world perception $[12$, p. 6]. Considering the causality of the writer's plots, the researcher notes that "eventivity of Gogol's plots keeps on mystical edge and, thus, is justified by "anti-logic" of the eventfultemporal dimension" [12, p. 7].

A.B. Yesin singles out such indicators of space and time as fullness and saturation as characteristics of Gogol's style. The researcher notes that Gogol's space is usually filled to the maximum with some objects, especially with things [13, p. 54].

Yu.M. Lotman considers Gogol's story "A Bewitched Place" to be an example of "pointlike" space-time [5]. O.G. Kovalchuk emphasizes that the devil "spoils" the ideal space in this story and makes it generate fear. In his view, the devil's favorite pastime is play with space, as a result of which several combinations of the same area appear in the story "A Bewitched Place". Moreover, spatial games may continue further - up to blurring the lines between the real and the fantastic worlds. In a moment, as in "May Night, or the Drowned Maiden", the real world becomes fantastic, and vice versa [14, p. 9].

Yu.M. Lotman points out that the specificity of perception of space by N.V. Gogol declared itself yet in his first cycle "Evenings on a Farm near Dikanka". "It is plain to see that everyday and fantastic scenes here, even within the bounds of the same story, are never localized in the same place" [5, p. 628].

A.S. Kichenko in his article "Evenings on a Farm Near Dikanka: Mythopoetic Organization of Space" notes that Gogol's ramified space of his first cycle (Sorochintsy, Dikanka, Mirgorod, Poltava, Gadyach, Baturin, Konotop) generates a set of mythologized allusions of Little Russia, thus confirming a "new" version of the romantic Ukrainian myth" [15, p. 56]. Analyzing the spatial mode of Gogol's "Evenings", the researcher distinguishes two semantic levels: cultural-historical and natural-landscape.

However, most studies have examined literary time and literary space separately. For example, in the article by Yu.M. Lotman "Literary space in Gogol's prose" the author does not set himself the task of examining literary time in the writer's works. The reason for this, according to N.D. Tamarchenko, is the emphasis on the traditional significance of certain forms, and not their role in the author's assessment of the hero and in the composition of stylistic harmony of a separate literary work [16, p. 179].

The theme of Ukraine is the key topic in the early prose of N.V. Gogol and, therefore, the categories of literary time and literary space are the most important plot-creating characteristics of the collections "Evenings" and "Mirgorod".

At present, the categories under consideration have been most fully analyzed in "Petersburg Tales", "Arabesques", "Dead Souls" and "The Government Inspector". As for the collections "Evening" and "Mirgorod", many researchers (N.A. Bondar, N.A. Kovaleva, V.Sh. Krivonos, S.V. Nevolchenko, V.V. Obraztsova, A.L. Petrova, B.A. Uspensky, T.P. Tselekhovich and others) illuminate time or space on the basis of one Gogol's story, highlighting the dominant, in their opinion, category, or consider the entire cycle through the prism of either spatial or temporal characteristics. In most of studies researchers analyze either time (E.E. Dmitrieva, A.B. Yesin, A.V. Kozlova, V.O. Sidorenko) or space (Yu.V. Vetchinkina, A.Kh. Goldenberg, I.A. Yesaulov, S.Z. Itkulov, N.I. IschukFadeeva, O.S. Karandashova, A.S. Kichenko, V.V. Kondratenko, V.Sh. Krivonos, Yu.M. Lotman, Yu.V. Mann, V.V. Markova, V.V. Maroshi, I.P. Megela, B.I. Nikolaev, M.A. Novikova and I.N. Shama, G.N. Pospelov, Yu. Rudnev, V.L. Skuratovsky, V.V. Tikhonova, V.N. Toporov, O.V. Fedulova, A. Hanzen-Loewe, S.O. Shvedova, V.G. Shchukin), less often - chronotope alone (M.M. Bakhtin, V.O. Korkishko, I.I. Merkulova).

However, this approach is not always justified, because in some of Gogol's stories, time plays a leading role, in others - space, in others - the complex interweaving and alternation of time and space, in the fourth - chronotopes and microchronotopes.

Conclusions. Literary time ("artistic time continuum"), literary space ("artistic space continuum") and "chronotope" determine the genre nature of the literary work, carry out narrative, plot-creating, character-creating functions. These categories are extremely important when analyzing any piece of fiction. Currently, there are many definitions and classifications of literary space and time.

The categories of literary space, literary time, and chronotope in Nikolai Gogol's prose have attracted attention of researchers since the 1970-s. Since the late 1980-s, there has been interest to the problem of microchronotopes, topoi and loci, chronotopic coordinates of the literary world and chronotopic characteristics of heroes, spatial and temporal motives (such as a dream motif or a road motif), deformations of space and time by unclean forces, etc. All these aspects of Gogol's worldbuilding have not been fully investigated and represent a vast field of study for Gogol scholars.

As a rule, when analyzing spatiotemporal structure of Gogol's prose, literary critics most often elucidate the opposition "our own/ alien" space, the antithesis "Dikanka - Petersburg", historical time in the stories "Christmas Eve", "The Lost Letter", "A Terrible Vengeance", "Taras Bulba". They are a kind of "chronotopic landmarks" that are mentioned in almost every second work.

A significant part researches is dedicated specifically to the category of space, as paramount in Gogol's works, while literary time is analyzed cursorily or as an integral part of the chronotope. The matters of the role and functions of the varieties of time and space used by the author, of the author's play with time, of the relationship between heroes and space in Gogol's stories require further study.

In Ukrainian literary criticism, interest to spatio-temporal problems in the works of N.V. Gogol has intensified only in the last decade. The history of chronotopic analysis of the writer's works is just beginning, which offers a broad field for research.

\section{References:}

1. Флоренский П.А. Анализ пространственности и времени в художественно-изобразительных произведениях. Исследования по теории искусства. Флоренский П.А. Статьи и исследования по истории и философии искусства и археологии. Москва : Мысль, 2000. C. 79-421. 
2. Бахтин М.М. Автор и герой в эстетической деятельности. Бахтин М.М. Работы 20-х годов. Киев : Next, 1994. С. 69-237.

3. Бахтин М.М. Формы времени и хронотопа в романе: очерки по исторической поэтике. Бахтин М.M. Вопросы литературы и эстетики. Москва : Художественная литература, 1975. С. 234-407.

4. Лихачев Д.С. Поэтика художественного времени. Поэтика художественного пространства. Лихачев Д.С. Поэтика древнерусской литературы. Москва, 1979. С. 209-351.

5. Лотман Ю.М. О русской литературе. Санкт-Петербург : Академия, $1997.848 \mathrm{c}$.

6. Топоров В.Н. Вещь в антропоцентрической перспективе (апология Плюшкина). Топоров В.Н. Миф. Ритуал. Символ. Образ: исследования в области мифопоэтического: избранное. Москва, 1995. С. 7-112.

7. Пятигорский А.М. Непрекращаемый разговор. Санкт-Петербург : Азбука-классика, 2004. 432 с

8. Павельева А.К. Виды и функции художественного пространства в литературном произведении. Південний архів. Філологічні науки : збірник наукових праць. Херсон, 2012. Вип. LIII. С. 76-81.

9. Павельева А.К. Проблемы изучения категорий художественного времени и пространства в литературоведении: теоретический аспект. Литературный текст ХХ века: проблемы поэтики : материалы V Международной научно-практической конференции. Челябинск : Цицеро, 2012. С. 286-294.

10. Литературный энциклопедический словарь / под общ. ред. В.М. Кожевникова, П.А. Николаева. Москва : Советская энциклопедия, $1987.752 \mathrm{c}$.

11. Літературознавчий словник-довідник / за ред. Р.Т. Гром'яка, Ю.І. Коваліва, В І. Терешка. Київ : Академія, 2006. 752 с.

12. Бовсунівська Т.В. Містична каузальність гоголівських сюжетів. Українська мова та література. 1999. № 12. С. 6-7.

13. Есин А.Б. Принципы и приемы анализа литературного произведения : учебное пособие. Москва : Флинт ; Наука, 2003. 248 с.

14. Ковальчук О.Г. Гоголь: буття і страх. Зарубіжна література. 2002. № 36. С. 3-9.

15. Киченко А.С. «Вечера на хуторе близ Диканьки» Гоголя: мифопоэтическая организация пространства. Нові гоголезнавчі студії. Сімферополь : Кримський Архів, 2005. Вип. 2(13). С. 55-64.

16. Тамарченко Н.Д., Тюпа В.И, Бройтман С.Н. Художественное время, пространство, событие. Тамарченко Н.Д., Тюпа В.И, Бройтман С.Н. Теория литературы : учебное пособие : в 2 т. Москва : Академия, 2004. Т. 1 : Теория художественного дискурса. Теоретическая поэтика. С. 179-186.
Павельсва А. К., Радченко Ю. С. Художній час та художній простір у прозі Миколи Гоголя: теоретичний аспект

Анотація. Статтю присвячено актуальній проблемі дефініції категорій «художній час», «художній простір», «хронотоп» та їх вивченню у вітчизняному літературознавстві XX-XXI століть. Аналізуються основні тенденції просторово-часової організації художнього твору, роль і функції категорій художнього часу, художнього простору та хронотопу для розуміння поетики окремого взятого твору та всієї творчості письменника загалом, зокрема філософії, світовідчуття і світосприйняття автора. Художній час, художній простір та хронотоп - це найважливіші характеристики художнього образу, які забезпечують цілісне сприйняття художньої дійсності та організовують композицію твору, відтворюють просторово-часову картину світу в символіко-ідеологічному й ціннісному аспектах. Зазначається, що художній час має свою специфіку в окремих видах художнього простору, виокремлюються основні різновиди художнього часу та художнього простору в літературному творі, а також їхні основні характеристики (наприклад, насиченість часу подіями або простору речами). Розглядаються ключові напрями вивчення вказаних категорій у світовому літературознавстві загалом та у творчості Миколи Гоголя зокрема. Виокремлюються просторово-часові орієнтири творів письменника, які найбільш часто ставали об'єктом дослідження (опозиція «свій/чужий простір», протиставлення «Диканька - Петербург», історичний час, хронотопічні мотиви сну й дороги, «ігри» нечистої сили 3 простором, залежність художнього простору від містики у творі тощо). Зазначається, що найчастіше дослідники аналізували саме категорію художнього простору як основний сюжетотворчий і характеротворчий художній засіб створення романтичного двосвіття ранньої прози М.В. Гоголя, натомість категорії художнього часу та хронотопу вивчені не досить. Автори статті підкреслюють, що просторово-часова картина світу творів Миколи Гоголя має розглядатися як складний синтез різних видів художнього часу, художнього простору, хронотопів, мікрохронотопів, топосів, локусів і хронотопічних мотивів у їхньому зв'язку із системою персонажів та родожанровою природою творів.

Ключові слова: художній час, художній простір, хронотоп, хроноотопічний мотив, топос, локус, картина світу, хронотопічний орієнтир. 